\title{
ANALISIS PENGELOLAAN SISTIM KEARSIPAN STATIS PADA DINAS PERPUSTAKAAN DAN KEARSIPAN KOTA PEKANBARU
}

\author{
Virna Museliza, SE, M.Si
}

\author{
Fakultas Ekonomi Dan Ilmu Sosial Uin Sultan Syarif Kasim Riau \\ Email : vmuseliza66@gamil.com
}

\begin{abstract}
Static archive management includes static archive acquisition activities, static archive processing, static archive preservation and static archive access. While the static archive according to Government Regulation of the Republic of Indonesia number 28 of 2012 concerning archives, is an archive produced by the creator of the archive because it has historical value, has retired, and is enlightened that has been verified directly or indirectly by the national archives of the Republic of Indonesia and / or archiving institutions. While the management of Static Archives in a professional manner aims to ensure the safety of static archives as a national responsibility for the life of the community, nation and state so that they can be accessed openly by the wider community in order to fulfill the right to obtain information in various needs and interests. The Research Objectives are to find out the Analysis of Static Filing System Management at the Library and Archives Office of the City of Pekanbaru and to find out what are the obstacles faced in the Management of Static Filing Systems at the Library and Archives Office of Pekanbaru City. The results showed that static file acquisition, static file processing, static archive preservation and static archive access were in accordance with Republic of Indonesia Government Regulation number 28 of 2012 concerning archives. Constraints faced are a). Human Resources namely Lack of human resources who have expertise in the field of filing and Substitution Officials and Staff of the Pekanbaru City Library and Archives Office are conducted so that it takes time to understand and know in the field of archives.b). Budget namely Lack of budget for training human resources in the field of filing and Lack of budget for the provision offacilities and infrastructures so that the storage space is insufficient for storing static archives and supporting facilities for storage rooms such as air conditioners, lighting and shelves or storing cabinets static archive. c). Facilities and Infrastructure, which are less extensive space for static archive storage so that the static archive is not neatly arranged, Lack of facilities and infrastructure such as cabinets, shelves and filling cabinets for storing static records, Lack of lighting so that the room is not too bright, Lack of air conditioning so the room is uncomfortable, and lack of air circulation so that the static archive storage room smells bad.
\end{abstract}


Keywords: Static Archive Management, Acquisition of Static Archives, Static Archive Processing, Static Archive Preservation and Static Archive Access

\begin{abstract}
Abstrak
Untuk mewujudkan penyelenggaraan kearsipan nasional yang komprehensif dan terpadu, lembaga kearsipan nasional perlu membangun suatu Sistem Kearsipan Nasional. Sistem Kearsipan Nasional ini berfungsi untuk menjamin ketersediaan arsip yang autentik, utuh, terpercaya, dan mengidentifikasi keberadaan arsip yang memiliki keterkaitan informasi sebagai satu keutuhan informasi di semua organisasi kearsipan. Selain itu, Sistem Kearsipan Nasional ini juga digunakan sebagai acuan dalam penyelenggaraan kearsipan oleh lembaga kearsipan dan pencipta arsip, yang didukung oleh sumber daya manusia, prasarana dan sarana, serta sumber daya lain sesuai dengan ketentuan peraturan perundang-undangan.

Pengelolaan arsip statis meliputi kegiatan akuisisi arsip statis, pengolahan arsip statis, preservasi arsip statis dan akses arsip statis. Sedangkan Arsip statis menurut Peraturan Pemerintah Republik Indonesia nomor 28 tahun 2012 tentang kearsipan, adalah arsip yang dihasilkan oleh pencipta arsip karena memiliki nilai guna kesejarahan, telah habis masa retensinya, dan berketerangan dipermanenkan yang telah diverifikasi baik secara langsung maupun tidak langsung oleh arsip nasional Republik Indonesia dan / atau lembaga kearsipan. Sedangkan pengelolaan Arsip Statis secara profesional bertujuan untuk menjamin keselamatan arsip statis sebagai pertanggungjawaban nasional bagi kehidupan bermasyarakat, berbangsa, dan bernegara sehingga pada akhirnya dapat diakses secara terbuka oleh masyarakat luas dalam rangka pemenuhan hak untuk memperoleh informasi dalam berbagai kebutuhan dan kepentingan. Tujuan Penelitian yaitu Untuk mengetahui Analisis Pengelolaan Sistim Kearsipan Statis Pada Dinas Perpustakaan dan Kearsipan Kota Pekanbaru dan Untuk mengetahui Apa saja kendala-kendala yang dihadapi dalam Pengelolaan Sistim Kearsipan Statis Pada Dinas Perpustakaan dan Kearsipan Kota Pekanbaru. Hasil penelitian menunjukkan akuisisi arsip statis, pengolahan arsip statis, preservasi arsip statis dan akses arsip statis sudah sesuai dengan Peraturan Pemerintah Republik Indonesia nomor 28 tahun 2012 tentang kearsipan. Kendala kendala yang dihadapi adalah a). Sumber Daya Manusia yaitu Kurangnya sumber daya manusia yang mempunyai keahlian di bidang kearsipan dan Pergantian Pejabat dan Staf Dinas Perpustakaan dan Kearsipan Kota Pekanbaru yang dilakukan sehingga dibutuhkan waktu untuk memahami dan mengetahui di bidang kearsipan.b). Anggaran yaitu Kurangnya anggaran untuk pelatihan sumber daya manusia di bidang kearsipan dan Kurangnya anggaran untuk penyediaan sarana dan prasana sehingga ruangan tempat penyimpanan tidak mencukupi untuk menyimpan arsip statis serta sarana pendukung ruangan penyimpanan seperti alat pendingin ruangan, lampu penerangan dan rak-rak atau lemari tempat
\end{abstract}


menyimpan arsip statis. c).Sarana dan Prasarana yaitu Kurang luasnya ruangan tempat penyimpanan arsip statis sehingga arsip statis tidak tertata dengan rapi, Kurangnya Sarana dan Prasarana seperti lemari, rak-rak dan filling cabinet untuk menyimpan arsip statis, Kurangnya lampu penerangan sehingga ruangan tersebut tidak terlalu terang, Kurangnya alat pendingin ruangan sehingga ruangan tersebut tidak nyaman, dan Kurangnya sirkulasi udara sehingga ruangan penyimpanan arsip statis tersebut berbau tidak sedap.

Kata Kunci : Pengelolaan Arsip Statis, Akuisisi Arsip Statis, Pengolahan Arsip Statis, Preservasi Arsip Statis Dan Akses Arsip Statis

PENDAHULUANDalam rangka mewujudkan dan mempertahankan Negara Kesatuan

Republik Indonesia, arsip sebagai bagian dari identitas bangsa berperan sebagai salah satu sarana penyelamatan wilayah negara dan simpul pemersatu bangsa. Oleh karena itu, arsip perlu diselamatkan sebagai bukti rekaman penyelenggaran kehidupan bermasyarakat,

berbangsa dan bernegara.

Dalam upaya mewujudkan penyelenggaraan kehidupan bermasyarakat, berbangsa dan bernegara yang baik dan bersih serta dalam menjaga agar dinamika gerak maju masyarakat, bangsa, dan negara ke depan senantiasa berada pada pilar perjuangan mencapai cita-cita nasional, arsip yang tercipta harus dapat menjadi sumber informasi, acuan, dan bahan pembelajaran masyarakat, bangsa, dan negara.

Oleh karena itu setiap lembaga negara, pemerintahan daerah, lembaga pendidikan, organisasi politik, organisasi kemasyarakatan, perusahaan dan perseorangan harus menunjukkan tanggung jawabnya dalam penyelenggaraan, penciptaan, pengelolaan, dan pelaporan arsip yang tercipta dari kegiatan-kegiatannya.

Selanjutnya, untuk mewujudkan penyelenggaraan kearsipan nasional yang komprehensif dan terpadu, lembaga kearsipan nasional perlu membangun suatu Sistem Kearsipan Nasional. Sistem Kearsipan Nasional ini berfungsi untuk menjamin ketersediaan arsip yang autentik, utuh, terpercaya, dan mengidentifikasi keberadaan arsip yang memiliki keterkaitan informasi sebagai satu keutuhan informasi di semua organisasi kearsipan. Selain itu, Sistem Kearsipan Nasional ini juga digunakan sebagai acuan dalam penyelenggaraan kearsipan oleh lembaga kearsipan dan pencipta arsip, yang didukung oleh sumber daya manusia, prasarana dan sarana, serta sumber daya lain sesuai dengan ketentuan peraturan perundangundangan.

Adapun pembangunan Sistem Kearsipan Nasional ini meliputi penetapan kebijakan, pembinaan kearsipan, dan pengelolaan arsip. Pengelolaan arsip dalam 
Sistem Kearsipan Nasional meliputi pengelolaan arsip dinamis dan pengelolaan arsip statis.

Pengelolaan arsip statis meliputi kegiatan akuisisi arsip statis, pengolahan arsip statis, preservasi arsip statis dan akses arsip statis.

Sedangkan Arsip statis menurut Peraturan Pemerintah Republik Indonesia nomor 28 tahun 2012 tentang kearsipan, adalah arsip yang dihasilkan oleh pencipta arsip karena memiliki nilai guna kesejarahan, telah habis masa retensinya, dan berketerangan dipermanenkan yang telah diverifikasi baik secara langsung maupun tidak langsung oleh arsip nasional Republik Indonesia dan / atau lembaga kearsipan.

Sedangkan pengelolaan Arsip Statis secara profesional bertujuan untuk menjamin keselamatan arsip statis sebagai pertanggungjawaban nasional bagi kehidupan bermasyarakat, berbangsa, dan bernegara sehingga pada akhirnya dapat diakses secara terbuka oleh masyarakat luas dalam rangka pemenuhan hak untuk memperoleh informasi dalam berbagai kebutuhan dan kepentingan.

Semenjak tahun 2016 Badan Perpustakaan dan Arsip telah berubah menjadi Dinas Perpustakaan dan Kearsipan Kota Pekanbaru, dimana setelah berubah menjadi Dinas Perpustakaan dan Kearsipan Kota Pekanbaru di dalam pelaksanaan tugasnya terpisah artinya Perpustakaan Mempunyai Kepala Bidang Perpustakaan khusus melaksanakan tugas mengenai Perpustakaan begitu pula dengan Arsip mempunyai Kepala Bidang Kearsipan yang melaksanakan tugas mengenai kearsipan menjadi lebih fokus.

Dalam Pengelolaan Arsip Statis Dinas Perpustakaan dan Arsip Kota Pekanbaru menggunakan Peraturan Pemerintah Republik Indonesia nomor 28 tahun 2012 tentang kearsipan dan Peraturan ini merupakan penyempurnaan dari Undang-Undang Republik Indonesia Nomor 43 Tahun 2009 tentang Kearsipan.

Di dalam Peraturan Pemerintah Republik Indonesia Nomor 28 Tahun 2012 Pasal 90 tentang Pengelolaaan arsip statis wajib dilakukan oleh : a). ANRI sebagai lembaga kearsipan nasional; b). Lembaga kearsipan provinsi; c). Lembaga kearsipan kabupaten/kota; dan d). Lembaga kearsipan perguruan tinggi negeri.

Penyerahan arsip statis oleh pencipta arsip kepada lembaga kearsipan dilakukan terhadap arsip yang:

a. Memiliki nilai guna kesejarahan;

b. Telah habis retensinya; dan/atau

c. Berketerangan dipermanenkan sesuai JRA pencipta arsip.

Arsip statis yang diserahkan oleh pencipta arsip kepada lembaga kearsipan harus merupakan arsip yang autentik, terpercaya, utuh, dan dapat digunakan.

Tabel 1.1.

Jenis Dokumen Arsip Statis 


\begin{tabular}{|c|c|c|c|c|}
\hline No. & Jenis Dokumen & Tahun & $\begin{array}{l}\text { Jumlah } \\
\text { Berkas }\end{array}$ & $\begin{array}{c}\text { Jumlah } \\
\text { Box }\end{array}$ \\
\hline 1 & $\begin{array}{lr}\text { Pengolahan } & \text { Arsip } \\
\text { Sekretariat } & \text { Bagian } \\
\text { Hukum } & \end{array}$ & 2015 & 1.354 & 45 \\
\hline 2 & Pengolahan Arsip Statis & $\begin{array}{l}2015 \\
2016\end{array}$ & $\begin{array}{l}490 \\
152\end{array}$ & $\begin{array}{l}34 \\
15\end{array}$ \\
\hline 3 & Pengolahan Arsip Foto & 2016 & 668 & - \\
\hline 4. & Arsip Kartografi & 2016 & 44 & - \\
\hline & JUMLAH & & 2.708 & 94 \\
\hline
\end{tabular}

Sumber : Dinas Perpustakaan dan Kearsipan Kota Pekanbaru Tahun 2017

Dari tabel diatas dapat dilihat bahwa Dokumen Arsip Statis mulai disimpan di Dinas Perpustakaan dan Kearsipan Kota Pekanbaru pada Tahun 2015 bahkan Arsip Foto dan Arsip Kartografi dimulai pada Tahun 2016 ini menunjukkan tidak adanya kepercayaan dan kesadaran setiap SKPD untuk menyimpan arsip statisnya di Dinas Perpustakaan dan Kearsipan Kota Pekanbaru sesuai dengan hasil wawancara pra riset yang telah dilakukan pada tanggal 16 Pebuari 2017.

Berdasarkan pra riset yang dilakukan pada tanggal 16 Pebuari 2017 di Dinas Perpustakaan dan Kearsipan Kota Pekanbaru melakukan wawancara langsung dengan Kepala Bidang Kearsipan yaitu Ibu Sri Irawani, SH, M.Si hasil wawancaranya adalah sebagai berikut :

"Secara teori Dinas Perpustakaan dan Kearsipan menyimpan arsip statis dalam Jadwal Retensi Arsip yaitu arsip yang permanen atau tetap misalnya sertifikat, penetapan surat-surat kecamatan dan kelurahan tetapi masalahnya setiap SKPD merasa keberatan untuk memberikan surat-suratnya karena SKPD juga membutuhkan dan kesadaran setiap SKPD untuk menyimpan arsip statis, selain itu tingkat kepercayaan kurang karena ada ketakutan arsipnya akan dilihat oleh yang tidak berkepentingan dan ketika SKPD membutuhkan arsip itu ada prosedur yang harus dilalui sehingga akan membutuhkan waktu untuk mendapatkan arsip itu"

Berdasarkan hasil wawancara dengan Ibu Sri Irawani, SH, M.Si dapat diambil kesimpulan bahwa :

a. Setiap SKPD Keberatan untuk menyimpan arsip statisnya di Dinas Perpustakaan dan Kearsipan Kota Pekanbaru karena setiap SKPD masih membutuhkan arsip statis tersebut;

b. Tingkat Kepercayaan yang kurang kepada Dinas Perpustakaan dan Kearsipan Kota Pekanbaru karena ada ketakutan akan kerahasiaan dari Arsip statis yang disimpan tersebut;

c. Adanya prosedur yang harus dilaksanakan ketika SKPD membutuhkan arsip statis tersebut sehingga membutuhkan waktu yang lama untuk menerima arsip statis tersebut. 
Dari uraian di atas penulis tertarik untuk melakukan penelitian tentang "Analisis Pengelolaan Sistim Kearsipan Statis Pada Dinas Perpustakaan dan Kearsipan Kota Pekanbaru"

\section{Rumusan Masalah}

Dari latar belakang permasalahan penelitian, peneliti merasa perlu merumuskan permasalahan tersebut dengan rumusan masalahnya adalah :

a. Bagaimana Analisis Pengelolaan Sistim Kearsipan Statis Pada Dinas Perpustakaan dan Kearsipan Kota Pekanbaru?

b. Apa saja kendala-kendala yang dihadapi dalam Pengelolaan Sistim Kearsipan Statis Pada Dinas Perpustakaan dan Kearsipan Kota Pekanbaru?

\section{Tujuan Penelitian}

a. Untuk mengetahui Analisis Pengelolaan Sistim Kearsipan Statis Pada Dinas Perpustakaan dan Kearsipan Kota Pekanbaru;

b. Untuk mengetahui Apa saja kendala-kendala yang dihadapi dalam Pengelolaan Sistim Kearsipan Statis Pada Dinas Perpustakaan dan Kearsipan Kota Pekanbaru.

\section{TINJAUAN PUSTAKA}

\section{Pengertian Arsip Statis}

Arsip adalah rekaman kegiatan atau peristiwa dalam berbagai bentuk dan media sesuai dengan perkembangan teknologi informasi dan komunikasi yang dibuat dan diterima oleh lembaga negara, pemerintahan daerah, lembaga pendidikan, perusahaan, organisasi politik, organisasi kemasyarakatan, perseorangan dalam pelaksanaan kehidupan bermasyarakat, berbangsa dan bernegara.

Arsip statis adalah arsip yang dihasilkan oleh pencipta arsip karena memiliki nilai guna kesejarahan, telah habis retensinya, dan berketerangan dipermanenkan yang telah diverifikasi baik secara langsung maupun tidak langsung oleh Arsip Nasional Republik Indonesia dan/atau lembaga kearsipan.

\section{Tujuan Kearsipan}

Tujuan kearsipan adalah memberikan pelayanan dalam penyimpanan arsip dan mampu menyediakan informasi dengan tepat, lengkap, akurat dan relevan, dan tepat waktu secara efisien, menyelamatkan bahan pertanggung jawaban nasional tentang penyelenggaraan pelaksanaan dan penyelenggaraan kehidupan kebangsaan.

\section{Jenis - jenis arsip}

Bentuk Arsip bisa beragam, tidak hanya berupa lembaran kertas dan tulisan seperti yang kerap dianggap oleh kebanyakan orang. Namun, dalam sebagian besar di kantor, arsip memang berupa kertas atau dokumen berbentuk lembaran kertas bertulisan. Kita dapat membedakan beberapa jenis arsip sebagai berikut : 
a. Arsip Menurut Subyek atau Isinya :

1. Arsip Kepgawaian

Contoh : data riwayat hidup pegawai, surat lamaran, surat pengangkatan pegawai, rekaman presensi dan sebagainya.

\section{Arsip Keuangan}

Contoh : laporan keuangan, bukti pembayaran, daftar gaji, bukti pembelian, surat perintah membayar.

3. Arsip Pemasaran

Contoh : surat penawaran, surat pesanan, surat perjanjian penjualan, daftar pelanggan, daftar harga dan sebagainya.

4. Arsip Pendidikan

Contoh : kurikulum, satuan pelajaran, daftar hadir siswa, rapor, transkrip mahasiswa dan sebagainya.

b. Arsip menurut Tingkat Penyimpanan dan Pemeliharaan :

1. Arsip Sentral

Arsip sentral yaitu arsip yang disimpan pada pusat arsip atau arsip yang dipusatkan penyimpanannya, arsip ini berada di unit kearsipan.

2. Arsip Unit

Arsip Unit yaitu arsip yang disimpan di setiap bagian atau setiap unit dalam suatu organisasi, arsip berada di unit pengolah.

c. Arsip Menurut Nilai atau Kegunaannya

Penggolongan arsip lebih didasarkan pada nilai dan kegunaannya. Dalam penggolongan ini ada bermacam-macam arsip yaitu :

1. Arsip bernilai Informasi

Contoh : pengumuman, pemberitahuan, undangan dan sebagainya.

2. Arsip bernilain Administrasi

Conoth : ketentuan-ketentuan organisasi, surat keputusan, surat prosedur kerja, dan sebagainya.

3. Arsip Bernilai Hukum

Contoh : akte pendirian perusahaan, akte kelahiran, akte perkawinan, surat perjanjian, keputusan peradilan, dan sebagainya.

4. Arsip bernilai sejarah

Contoh : laporan tahunan, notulen rapat, gambar/foto peristiwa, dan sebagainya.

5. Arsip bernilai ilmiah yaitu Hasil penelitian.

d. Arsip menurut Sifat Kepentingan

Penggolongan ini lebih didasarkan pada sifat kepentingannya atau urgensinya, dalam penggolongan ini ada beberapa macam arsip, yaitu :

1. Arsip Tidak Berguna

Contoh : surat undangan, memo dan sebagainya.

2. Arsip berguna 
Contoh : presensi pegawai, surat permohonan cuti, surat pesanan barang dan sebagainya.

3. Arsip penting

Contoh : surat keputusan, daftar riwayat hidup pegawai, laporan keuangan, buku kas, daftar gaji dan sebagainya.

4. Arsip Vital

Contoh : akte pendirian perusahaan, buku untuk pegawai, sertifikat tanah/bangunan, ijazah dan sebagainya.

e. Arsip menurut keasliannya

Menurut keasliannya, arsip dibedakan atas :

1. Arsip Asli

Arsip Asli adalah dokumen yang langsung terkena hentakan mesin ketik, cetakan printer, dengan tanda tangan dan legalitas yang asli, yang merupakan dokumen utama.

2. Arsip Tembusan

Arsip Tembusan yaitu dokumen kedua, ketiga dan seterusnya, yang dalam proses pembuatannya bersama dengan dokumen asli, tetapi ditujukan pada pihak lain selain penerima dokumen asli.

3. Arsip Salinan

Arsip Salinan yaitu dokumen yang proses pembuatannya tidak bersama dokumen asli. Tetapi memiliki kesuaian dengan dokumen asli.

\section{Arsip Petikan}

Arsip Petikan yaitu dokumen yang berisi bagian dari suatu dokumen asli.

f. Arsip Menurut Bentuk dan Wujud Fisik

Penggolongan ini lebih didasarkan pada tampilan fisik media yang digunakan dalam merekam informasi. Menurut bentuk dan wujud fisiknya arsip dapat dibedakan menjadi :

1. Surat

Contoh : naskah perjanjian/kontrak, akte pendirian perusahaan, surat keputusan, notulen rapat, berita acara, laporan, tabel dan sebagainya.

2. File rekaman;

3. Microfilm;

4. Disket;

5. Compact Disk (CD).

g. Arsip menurut Fungsinya

Penggolongan ini lebih didasarkan pada Fungsi arsip dalam mendukung kegiatan organisasi. Dalam penggolongan ini ada dua jenis arsip yaitu :

1. Arsip Dinamis yaitu arsip yang masih dipergunakan secara langsung dalam kegiatan perkantoran sehari-hari.

2. Arsip Statis yaitu : arsip yang sudah tidak dipergunakan secara langsung dalam kegiatan perkantoran sehari-hari. 


\section{Peranan Arsip}

Sebagai sumber informasi, maka arsip dapat membantu mengingatkan dalam rangka pengambilan keputusan secara cepat dan tepat mengenai sesuatu masalah. berikut :

Menurut Sedarmayanti (2013) peranan arsip dapat disimpulkan sebagai

a. Alat utama ingatan organisasi;

b. Bahan atau alat pembuktian (bukti otentik);

c. Bahan dasar perencanaan dan pengambilan keputusan;

d. Barometer kegiatan suatu organisasi mengingat setiap kegiatan pada umumnya menghasilkan arsip;

e. Bahan informasi kegiatan ilmiah lainnya.

\section{Tahapan Arsip}

a. Tahap Penciptaan

Tahapan ini merupakan tahapan awal dari proses kehidupan arsip yaitu yang bentuknya masih berupa konsep daftar formulir. Tahap ini dapat disebut tahapan korespondensi manajemen.

b. Tahap Pengurusan dan Pengendalian

Pada tahapan ini merupakan tahapan dimana surat keluar dan masuk diregistrasi, diagendakan sesuai dengan sistim yang telah ditentukan setelah itu surat-surat tersebut di arahkan dan di kendalikan ditempat yang akan membahas dan memproses surat tersebut.

c. Tahap Reprensi

Pada tahapan ini surat-surat digunakan dalam kegiatan organisasi di unit pengelola;

dan surat tersebut diklasifikasikan diindeks bila perlu digunakan tunjuk silang selesai di filling agar saat dibutuhkan dapat cepat ditemukan kembali.

d. Tahap penyusutan

Tahap ini merupakan tahap pengurangan arsip dengan cara memindahkan arsip inaktip dari unit pengelola ke unit kearsipan dalam lingkungan lembagalembaga negara, badan-badan pemerintah dari hasil kegiatan penyusutan ini akan terdapat 3 (tiga) jenis arsip yaitu :

1. Arsip yang masih aktif yang digunakan dalam kegiatan sehari-hari tetapi disimpan di unit pengelola.

2. Arsip yang tidak penting, non aktif misalnya formulir kosong tembusan yang rangkap dobel arsip yang tidak penting langsung dapat dimusnahkan.

3. Arsip penting yang sudah menurun kegunaannya langsung dipindah ke unit kearsipan menjadi arsip inaktif perlu diketahui penyusutan juga dapat terjadi diunit kearsipan yaitu penyusutan arsip inaktif kegiatan ini biasanya dilakukan oleh suatu panitia penyusutan, pemusnahan arsip ini dibentuk oleh 
lembaga-lembaga Negara dan dilaksanakan oleh arsip Nasional dengan melihat kegunaan, informasi yang terkandung dalam arsip tersebut.

e. Tahap Pemusnahan

Tahapan ini merupakan tahapan dimana arsip dimusnahkan dan pemusnahan dapat dilakukan oleh lembaga negara, badan-badan pemerintah, arsip yang dimusnahan arsip yang sudah tidak memiliki nilai guna, telah melampaui batas waktu penyimpanan sebagaimana tercantum sebagai jadwal retensi.

f. Tahap Penyimpanan

Dalam tahapan ini arsip aktip setelah diseleksi maka akan mendapat 2 (dua) jenis arsip yang masih tetap digunakan dalam kegiatan sehari-hari dan arsip yang sudah menurun nilai gunanya sehingga dapat dikatakan arsip inaktif dan arsip tersebut didaftarkan dan dipindahkan ke lembaga kearsipan di instansi masing-masing.

g. Tahap Penyerahan arsip ke Arsip Nasional

Pada tahapan ini merupakan tahap terakhir dalam lingkungan arsip-arsip yang sudah menjadi arsip inaktif yang sudah menjadi statis di serahkan oleh lembaga ke Arsip Nasional RI kemudian lembaga arsip nasional menyimpan, memelihara sebagai pertanggung jawaban Nasional sebagai bahan bukti.

\section{Penyerahan Arsip Statis}

Peraturan Pemerintah Republik Indonesia Nomor 28 Tahun 2012 pada pasal 84 tentang Penyerahan arsip statis yaitu :

a. Arsip statis pemerintahan daerah kabupaten/kota wajib diserahkan kepada lembaga kearsipan daerah kabupaten/kota.

b. Penetapan arsip statis pada pemerintahan daerah kabupaten/kota sebagaimana ditetapkan oleh bupati/walikota.

c. Pelaksanaan penyerahan arsip statis yang memiliki retensi di bawah 10 (sepuluh) tahun menjadi tanggung jawab unit kearsipan di lingkungan satuan kerja perangkat daerah kabupaten/kota atau penyelenggara pemerintahan daerah kabupaten/ kota.

d. Pelaksanaan penyerahan arsip statis yang memiliki retensi sekurang-kurangnya 10 (sepuluh) tahun menjadi tanggung jawab lembaga kearsipan daerah kabupaten/kota.

\section{Pengelolaan Arsip Statis}

Berdasarkan Peraturan Pemerintah Republik Indonesia Nomor 28 Tahun 2012 Pasal 91 Pengelolaan arsip statis meliputi kegiatan:

a. Akuisisi arsip statis;

b. Pengolahan arsip statis;

c. Preservasi Arsip Statis;

d. Akses Arsip Statis.

\section{Pandangan Islam}


Berdasarkan pandangan Islam bahwa memelihara dan menjaga dokumen, disebutkan dalam Al-Qur'an. Serta menjelaskan, memelihara dan menjaga arsip atau dokumen sama dengan memelihara dan menjaga Al-Qur'an, yang jadi pedoman dan petunjuk kepada umat Islam. Sebagaimana Firman ALLAH SWT, sebagai berikut :

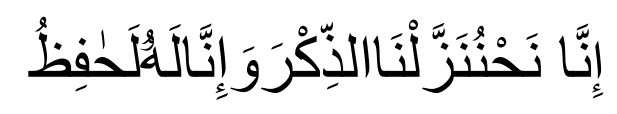

Artinya : "Sesungguhnya Kami-lah yang menurunkan Al-Qur'an, dan sesungguhnya, Kami benar-benar memeliharanya”. (Q.S, Al Hijr : 9)

Ayat- diatas memberikan jaminan tentang kesucian dan kemurnian AlQur'an selama-lamanya. Dan seperti itu juga arsip atau dokumen jika di tata rapi dan di jaga kerahasiannya.

\section{Penelitian Terdahulu}

Tabel 2.1.

Hasil Penelitian Terdahulu

\begin{tabular}{|c|c|c|c|}
\hline No. & Judul & Nama & Hasil \\
\hline 1. & \begin{tabular}{lrr} 
Strategi & \multicolumn{2}{r}{ Pengaturan } \\
Arsip & Statis & Pada \\
Lembaga & Kearsipan \\
Dalam & Upaya \\
Meningkatkan & Akses \\
dan Mutu & Layanan \\
Arsip Statis & Kepada \\
Publik & &
\end{tabular} & $\begin{array}{l}\text { Drs. Azmi, } \\
\text { M.Si }\end{array}$ & $\begin{array}{l}\text { Eksistensi Lembaga } \\
\text { Kearsipan sebagai wali arsip } \\
\text { statis pada era } \\
\text { reformasi dituntut untuk } \\
\text { responsif terhadap } \\
\text { perubahan-perubahan } \\
\text { lingkungan } \\
\text { strategis yang terjadi pada } \\
\text { saa ini, seperti good } \\
\text { governance, otonomi daerah, } \\
\text { perkembangan ilmu } \\
\text { pengetahuan di bidang } \\
\text { teknologi informasi dan } \\
\text { komunikasi, globalisasi, ilmu dan } \\
\text { arus globikn. } \\
\text { praktik kearsipan. }\end{array}$ \\
\hline 2. & $\begin{array}{lr}\text { Prosedur } & \text { Penataan } \\
\text { Arsip Di } & \text { Kantor } \\
\text { Perpustakaan } & \text { Arsip dan } \\
\text { Dokumentasi } & \text { Kota } \\
\text { Solok } & \end{array}$ & $\begin{array}{lr}\text { Refni } & \text { Darmen } \\
\text { dan } & \text { Elva } \\
\text { Rahmah } & \end{array}$ & $\begin{array}{l}\text { Prosedur Penataan Arsip } \\
\text { Pada Kantor Perpustakaan } \\
\text { Arsip dan Dokumentsi Kota } \\
\text { Solok, adalah menurut sistem } \\
\text { wilayah atau daerah-daerah } \\
\text { tempat pegawai bekerja. }\end{array}$ \\
\hline
\end{tabular}




\section{Definisi Konsep}

Berdasarkan uraian konsep diatas dapat dirumuskan definisi konsep karya ilmiah adalah sebagai berikut :

a. Arsip statis adalah arsip yang dihasilkan oleh pencipta arsip karena memiliki nilai guna kesejarahan, telah habis retensinya, dan berketerangan dipermanenkan yang telah diverifikasi baik secara langsung maupun tidak langsung oleh Arsip Nasional Republik Indonesia dan/atau lembaga kearsipan.

b. Pengelolaan arsip statis adalah proses pengendalian arsip statis secara efisien, efektif, dan sistematis meliputi akuisisi, pengolahan, preservasi, pemanfaatan, pendayagunaan, dan pelayanan publik dalam suatu sistem kearsipan nasional.

c. Proses pengendalian arsip statis secara efisien, efektif, dan sistematis meliputi akuisisi arsip statis, pengolahan arsip statis, preservasi arsip statis, akses arsip statis dalam suatu sistem kearsipan nasional.

d. Akuisisi arsip statis adalah proses penambahan khasanah arsip statis pada lembaga kearsipan yang dilaksanakan melalui kegiatan penyerahan arsip statis dan hak pengelolaannya dari pencipta arsip kepada lembaga kearsipan.

e. Pengolahan arsip statis adalah pengolahan yang dilaksanakan berdasarkan asas asal usul dan asas aturan asli serta standar deskripsi arsip statis.

f. Preservasi arsip statis yaitu pengelolaan yang dilaksanakan dengan cara preventif dan kuratif.

g. Akses arsip statis yaitu pengelolaan arsip statis yang dilaksanakan dalam rangka pemanfaatan, pendayagunaan, dan pelayanan publik.

\section{Konsep Operasional}

Tabel 2.2.

Konsep Operasional

\begin{tabular}{|c|c|c|}
\hline \multirow{5}{*}{\begin{tabular}{l}
\multicolumn{1}{c}{ Referensi } \\
Analisis \\
Pengelolaan \\
Sistim Kearsipan \\
Statis Pada Dinas \\
Perpustakaan dan \\
Kearsipan Kota \\
Pekanbaru. \\
Sumber : PP RI \\
No.28 Tahun 2012 \\
tentang Kearsipan
\end{tabular}} & Indikator & Sub Indikator \\
\hline & 1. Akuisisi Arsip Statis & $\begin{array}{l}\text { a. Penyerahan Arsip Statis; } \\
\text { b. Hak Pengelolaannya. }\end{array}$ \\
\hline & $\begin{array}{l}\text { 2. Pengolahan Arsip } \\
\text { Statis }\end{array}$ & $\begin{array}{l}\text { a. Asas Asal usul; } \\
\text { b. Asas Aturan Asli; } \\
\text { c. Standar Deskripsi. }\end{array}$ \\
\hline & 3. Preservasi Arsip Statis & $\begin{array}{l}\text { a. Preventif; } \\
\text { b. Kuratif. }\end{array}$ \\
\hline & 4. Akses Arsip Statis & $\begin{array}{l}\text { a. Pemanfaatan; } \\
\text { b. Pendayagunaan; } \\
\text { c. Pelayanan Publik. }\end{array}$ \\
\hline
\end{tabular}




\section{Kerangka Berpikir}

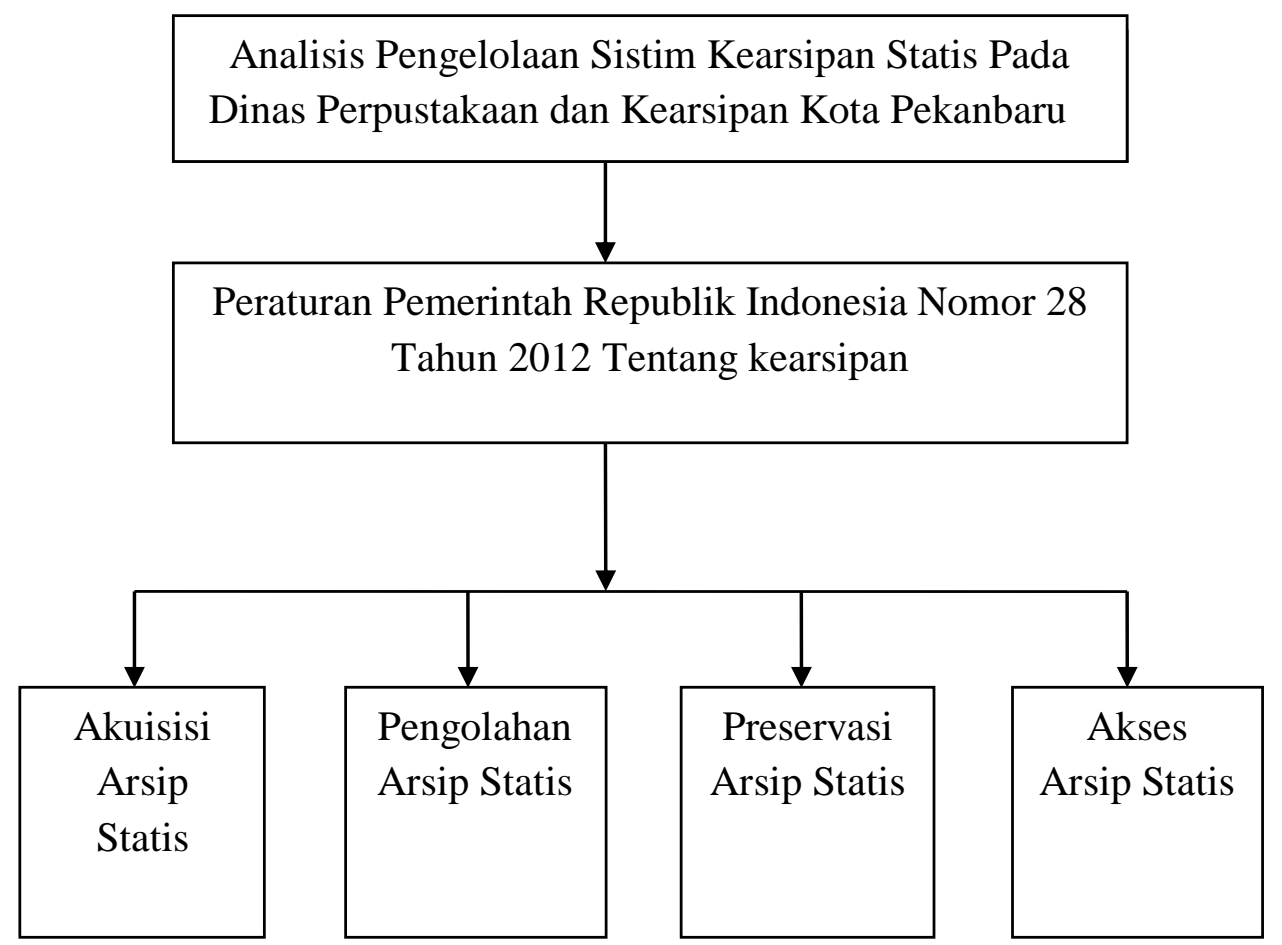

\section{METODOLOGI PENELITIAN}

\section{Lokasi dan Waktu Penelitian}

Penelitian ini rencananya akan dilakukan pada Dinas Perpustakaan dan Kearsipan Kota Pekanbaru untuk mengetahui Analisis Pengelolaan Sistim Kearsipan Statis Pada Dinas Perpustakaan dan Kearsipan Kota Pekanbaru. Adapun waktu penelitian ini dimulai dari bulan Oktber 2017 sampai selesai.

\section{Jenis Penelitian}

Jenis penelitian ini adalah penelitian kualitatif dengan pendekatan deskriptif.

\section{Sumber Data}

Adapun data yang diperlukan dalam penelitian ini meliputi : 
a. Data primer, berupa hasil wawancara dengan informan penelitian dan hasil penelusuran yang dilakukan langsung di lokasi penelitian yaitu Dinas Perpustakaan dan Kearsipan Kota Pekanbaru;

b. Data Sekunder, umumnya berupa bukti, catatan atau laporan historis yang telah tersusun dalam arsip (data dokumenter) yang dipublikasikan dan tidak dipublikasikan. Data Sekunder yang digunakan dalam penelitian ini adalah data dalam bentuk jadi yaitu Peraturan Pemerintah Republik Indonesia Nomor 28 Tahun 2012 Tentang Kearsipan.

\section{Teknik Pengumpulan Data}

Adapun teknik pengumpulan data dilakukan dengan :

a. Pengamatan (Observasi) yaitu dengan mengadakan pengamatan dan pencatatan secara langsung kepada obyek penelitian;

b. Wawancara (Interview) yaitu wawancara semi terstruktur wawancara ini termasuk dalam indepth interview, dimana dalam pelaksanaannya pewawancara membawa panduan pertanyaan lengkap dan terperinci untuk dimintai pendapat, pandangan, pengalaman, dan idenya sesuai dengan objek penelitian;

c. Dokumentasi yaitu teknik pengumpulan data melalui bahan-bahan tertulis yang diterbitkan oleh lembaga-lembaga yang menjadi obyek penelitian, baik berupa prosedur, peraturan, gambar, laporan hasil pekerjaan serta berupa foto.

\section{Informan Penelitian}

Penentuan sumber data pada orang yang diwawancarai dilakukan secara purposive yaitu dipilih dengan pertimbangan dan tujuan tertentu.

Tabel 3.1.

Key Informan

\begin{tabular}{|c|l|l|c|}
\hline No & \multicolumn{1}{|c|}{ Nama } & \multicolumn{1}{|c|}{ Jabatan } & Jumlah \\
\hline 1. & Ir. Hj. Nelfiyona, M.Si & Kepala Dinas & 1 Orang \\
\hline 2. & Sri Irawani, SH, M.Si & Kepala Bidang Kearsipan & 1 Orang \\
\hline 3. & Multi Feri, ST & Seksi Pengelolaan Arsip & 1 Orang \\
\hline
\end{tabular}

Sumber : Data Olahan Penelitian 2017

\section{Tekhnik Analisis Data}

Aktivitas dalam pengolahan dan analisis data kualitatif dilakukan secara interaktif yang terdiri dari empat langkah, yaitu:

a. Pengumpulan data, yaitu Pengumpulan data berarti proses memasuki lingkungan penelitian dan melakukan pengumpulan data penelitian;

b. Reduksi data, yaitu Mereduksi data berarti merangkum, memilih data yang pokok dan penting serta membuat katagorisasi. Dengan demikian data yang 
telah direduksi akan memberikan gambaran yang jelas sesuai dengan tujuan penelitian, dan mempermudah untuk melakukan pengumpulan data selanjutnya;

c. Penyajian data, yaitu Penyajian data dalam penelitian kualitatif bisa dilakukan dalam bentuk uraian singkat, bagan dan hubungan antar katagori. Selanjutnya diuraikan dalam penyajian data, berupa teks narasi;

d. Penarikan kesimpulan/verifikasi, yaitu Kesimpulan yang dikemukan jika didukung oleh bukti-bukti yang valid dan konsisten saat penelitian maka kesimpulan yang dikemukakan merupakan kesimpulan yang kredibel. Penarikan kesimpulan dilakukan dengan content analysis (teknik analisis isi) yaitu dengan membandingkan hasil penelitian dengan teori yang ada pada kajian teori.

e. Teknik analisis data dalam penelitian ini menggunakan model analisis interaktif.

\section{HASIL PENELITIAN DAN PEMBAHASAN}

Penelitian ini bertujuan untuk mengetahui Pengelolaan Sistim Kearsipan Statis Pada Dinas Perpustakaan dan Kearsipan Kota Pekanbaru dan Apa saja kendala-kendala yang dihadapi dalam Pengelolaan Sistim Kearsipan Statis Pada Dinas Perpustakaan dan Kearsipan Kota Pekanbaru.

Penelitian ini dilakukan di Dinas Perpustakaan dan Kearsipan Kota Pekanbaru.

Dalam latar belakang fenomena yang terjadi yaitu Setiap SKPD Keberatan untuk menyimpan arsip statisnya di Dinas Perpustakaan dan Kearsipan Kota Pekanbaru karena setiap SKPD masih membutuhkan arsip statis tersebut, Tingkat Kepercayaan yang kurang kepada Dinas Perpustakaan dan Kearsipan Kota Pekanbaru karena ada ketakutan akan kerahasiaan dari Arsip statis yang disimpan tersebut, Adanya prosedur yang harus dilaksanakan ketika SKPD membutuhkan arsip statis tersebut sehingga membutuhkan waktu yang lama untuk menerima arsip statis tersebut.

Fenomena diatas didukung berdasarkan hasil wawancara dengan Kepala Bidang Kearsipan yaitu Ibu Sri Irawani, SH, M.Si hasil wawancaranya adalah sebagai berikut :

"Secara teori Dinas Perpustakaan dan Kearsipan menyimpan arsip statis dalam Jadwal Retensi Arsip yaitu arsip yang permanen atau tetap misalnya sertifikat, penetapan surat-surat kecamatan dan kelurahan tetapi masalahnya setiap SKPD merasa keberatan untuk memberikan surat-suratnya karena SKPD juga membutuhkan dan kesadaran setiap SKPD untuk menyimpan arsip statis, selain itu tingkat kepercayaan kurang karena ada ketakutan arsipnya akan dilihat oleh yang tidak berkepentingan dan ketika SKPD membutuhkan arsip itu ada prosedur yang harus dilalui sehingga akan membutuhkan waktu untuk mendapatkan arsip itu”. 


\section{Sejarah Dinas Perpustakaan dan Kearsipan Kota Pekanbaru}

Cikal bakal Dinas Perpustakaan dan Kearsipan Kota Pekanbaru adalah keberadaan perpustakaan di Bagian Hubungan Masyarakat Sekretariat Daerah Kota Pekanbaru dan pembentukan Kantor Arsip dengan Peraturan Daerah Kota Pekanbaru nomor 8 Tahun 2001 tentang Perubahan Atas Peraturan Daerah Kota Pekanbaru Nomor 5 Tahun 2001 tentang Pembentukan Susunan Organisasi dan Tata Kerja Badan/Kantor di Lingkungan Pemerintah Kota Pekanbaru.

Penataan organisasi perangkat daerah dilakukan Pemerintah Kota Pekanbaru dengan membentuk Kantor Perpustakaan dan Arsip berdasarkan Peraturan Daerah Kota Pekanbaru Nomor 9 Tahun 2008 tentang Pembentukan Susunan Organisasi, Kedudukan dan Tugas Pokok Lembaga Teknis Daerah di Lingkungan Pemerintah Kota Pekanbaru.

Selanjutnya, berdasarkan Peraturan Daerah Kota Pekanbaru Nomor 10 Tahun 2013 tentang Perubahan Atas Peraturan Daerah Kota Pekanbaru Nomor 9 Tahun 2008 Dinas Perpustakaan dan Arsip Kota Pekanbaru terbentuk dan dikepalai oleh seorang Kepala yang membawahi Sekretariat dan 3 (tiga) bidang yaitu Bidang Pembinaan, Bidang Informasi Layanan dan Bidang Akuisisi, Deposit dan Pengolahan.

Dinas Perpustakaan dan Arsip Kota Pekanbaru mengelola Perpustakaan Umum Kota Pekanbaru, 4 Perpustakaan Keliling, 2 Taman Bacaan Masyarakat dan 1 Unit Pengelola Arsip Statis Kota Pekanbaru.

Selanjutnya, berdasarkan Peraturan Daerah Kota Pekanbaru Nomor 9 Tahun 2016 Tentang Pembentukan dan Susunan Perangkat Daerah Kota Pekanbaru Dinas Perpustakaan dan Kearsipan (DISPUSIP) Kota Pekanbaru terbentuk.

Dinas Perpustakaan dan Kearsipan Kota Pekanbaru dikepalai seorang Kepala yang membawahi Sekretariat dan 3 (tiga) bidang yaitu :

a. Bidang Pengolahan, Pelestarian dan Layanan Perpustakaan;

b. Bidang Pembinaan, Pengembangan Perpustakaan dan Pembudayaan Kegemaran Membaca;

c. Bidang Kearsipan.

Dinas Perpustakaan dan Kearsipan Kota Pekanbaru mengelola:

a. Perpustakaan Umum Kota Pekanbaru yang terletak di Jl. Dr. Sutomo No. 1 Pekanbaru;

b. 6 (enam) unit Mobil Perpustakaan Keliling;

c. 2 (dua) unit Taman Bacaan Masyarakat yang terletak di Jl. Tambelan Kecamatan Simpang Empat Pekanbaru dan Jl. Yos Sudarso Kecamatan Rumbai Pesisir;

d. Website Dinas Perpustakaan dan Kearsipan;

e. Perpustakaan digital iPekanbaru;

f. Unit Pengelola Arsip Statis Pemerintah Kota Pekanbaru.

Visi DISPUSIP Kota Pekanbaru

Mewujudkan Pekanbaru cerdas melalui gemar membaca dan sadar tertib arsip 


\section{Kepala Sub Bidang Pembinaan Kearsipan mempunyai rincian tugas:}

a. Merencakan dan melaksanakan program kerja Sub Bidang Pembinaan Kearsipan berdasarkan ketentuan peraturan perundang-undangan dan petunjuk atasan sebagai pedoman dalam pelaksanaan tugas;

b. Merumuskan dan melaksanakan penyelenggaraan peningkatan kemampuan pengelolaan kearsipan;

c. Melaksanakan dan memfasilitasi pembinaan kearsipan dan arsiparis;

d. Merumuskan dan melaksanakan pertimbangan atas pengangkatan dan pemberhentian jabatan fungsional arsiparis;

e. Merumuskan dan memfasilitasi penilaian dan penetapan angka kredit arsiparis;

f. Menyusun dan melaksanakan norma, standar, pedoman dan petunjuk operasional bidang pembinaan kearsipan;

g. Membagi tugas kepada bawahan dengan cara disposisi atau secara lisan agar bawahan mengetahui tugas dan tanggung jawab masing-masing;

h. Memberi petunjuk kepada bawahan dengan cara tertulis atau secara lisan agar pelaksanaan tugas efisien dan efektif;

i. Mengatur pelaksanaan tugas berdasarkan prioritas agar tugas dapat diselesaikan sesuai dengan sasaran yang telah ditetapkan;

j. Memfasilitasi tugas dengan cara konsultasi, kunjungan kerja, sosialisasi dan bimbingan teknis;

k. Mengevaluasi tugas berdasarkan informasi, data, laporan yang diterima untuk bahan penyempurnaan pelaksanaan tugas lebih lanjut;

1. Melaporkan pelaksanaan tugas kepada atasan secara lisan maupun tertulis; m. Melaksanakan tugas-tugas lain yang diberikan oleh pimpinan sesuai dengan tugas dan fungsinya.

\section{Analisis Pengelolaan Sistim Kearsipan Statis Pada Dinas Perpustakaan dan Kearsipan Kota Pekanbaru}

Untuk menganalisis Pengelolaan Sistim Kearsipan Statis Pada Dinas Perpustakaan dan Kearsipan Kota Pekanbaru dan Apa saja kendala-kendala yang dihadapi dalam Pengelolaan Sistim Kearsipan Statis Pada Dinas Perpustakaan dan Kearsipan Kota Pekanbaru.

Indikator tersebut merupakan inti dari analisis yang dilakukan yang diambil dari Peraturan Pemerintah Republik Indonesia Nomor 28 Tahun 2012 tentang Kearsipan. Dengan uraian hasil penelitian sebagai berikut :

\section{Akuisisi Arsip Statis}

Berdasarkan Peraturan Pemerintah Nomor 28 Tahun 2012 tentang Kearsipan, Akuisisi Arsip Statis adalah proses penambahan khasanah arsip statis pada lembaga kearsipan yang dilaksanakan melalui kegiatan penyerahan arsip statis dan hak pengelolaannya dari pencipta arsip kepada lembaga kearsipan.

Penyerahaan arsip statis dari pencipta arsip ke lembaga kearsipan di Pemerintah Kota Pekanbaru harus memiliki nilai guna kesejarahan, telah habis 
retensi masa simpannya dan berketerangan di permanenkan seusia dengan Jadwal Retensi Arsip.

Arsip yang seharusnya di simpan di lembaga kearsipan yaitu arsip yang memiliki nilai guna kseajarahan, telah habis retensinya dan berketrangan di permanenkan.

Penyerahan arsip statis wajib dilaksanakan oleh lembaga negara, pemerintah daerah, perguruan tinggi negeri, BUMN, BUMD dan perusahaan swasta kerana organisasi tersebut tidak mungkin tidak memiliki arsip statis. Arsip statis dari organisasi di atas merupakan arsip yang memiliki nilai guna kesejarahaan serta telah habis rentensinya. Maka dari itu arsip statis yang di miliki organisasi di atas wajib menyerahkan arsip statisnya ke lembaga kearsipannya.

Seharusnya perguruan tinggi baik negeri maupun swasta harus memiliki lembaga kearsipan. Namun dalam kenyataan banyak perguruan tinggi belum memiliki lembaga kearsipannya.

Arsip Perguruan Tinggi adalah lembaga kearsipan berbentuk satuan organisasi perguruan tinggi baik negeri maupun swasta yang melaksanakan fungsi dan tugas penyelenggaraan kearsipan di lingkungan perguruan tinggi.

Arsip statis yang ada di perguruan tinggi jika belum memiliki lembaga kearsipan wajib menyerahkan arsip statisnya ke lembaga kearsipan daerah untuk lebih terjamin penyimpanannya apalagi arsip statisnya berhubungan dengan anggaran negara atau APBD.

Penyerahan arsip statis menjadi tanggung jawab pimpinan pencipta arsip. karena pimpinan pencipta arsip yang akan menandatangan dan bertanggung jawab atas berita acara penyerahan arsip statis.

Prosedur penyerahan arsip statis yaitu :

a. Untuk pembuatan dan penyelesaian daftar arsip usul serah di buat oleh arsipararis. Tetapi jika perangkat daerah tidak memiliki arsiparis, pembuatan dan penyelesaian di kerjakan oleh pengelola arsip atau staf sesuai dengan peraturan perundang-undangan;

b. Penilaian oleh panitia penilai arsip usul serah dengan melihat nilai kesejarahan, retensi dan dipermanenkan apakah sesuai dengan JRA atau tidak;

c. Pimpinan pencipta arsip harus berkoordinasi dengan pimpinan lembaga kearsipan daerah untuk arsip yang akan diserahan sesuai dengan wilayah kewenangannya. Kemudian untuk nilai arsip statis autentik, terpercaya, utuh dan dapat di gunakan juga harus berkoordinasi dengan pimpinan lembaga kearsipan;

d. Verifikasi dan persetujuan untuk menyerahkan arsip statis harus sesuai dengan wilayah kewenangannya;

e. Arsip yang akan di serahkan oleh pencipta arsip harus ditetapkan arsip mana saja yang akan di serahkan;

f. Pelaksanaan penyerahan arsip statis wajib disertai dengan berita acara penyerahan dan daftar arsip yang akan di serahkan. Hal ini dilaksanakan untuk 
menjadi bahan bukti bagi lembaga kearsipan bahwa arsip-arsip apa saja yang di serrahkan ke lembaga kearsipan;

g. Menyerahkan arsip dilaksanakan dengan memperhatikan format dan media arsip guna menhetahui bentuk dan jenis arsip yang akan di serahkan.

Bahwa Hak Pengelolaan arsip statis yaitu :

a. Yang telah di serahkan ke lembaga kearsipan menjadi wewenang lembaga kearsipan;

b. Hak pengelolaan arsip statis perguruan tinggi swasta yang kegiatannya dibiayai dari anggaran negara atau APBD yang telah di serahkan ke lembaga kearsipan daerah menjadi wewenang lembaga kearsipan daerah.

\section{Pengolahan Arsip Statis}

Peraturan Pemerintah Republik Indonesia Nomor 28 Tahun 2012 tentang Kearsipan yang dimaksud dengan Pengolahan arsip statis adalah pengolahan yang dilaksanakan berdasarkan asas asal usul dan asas aturan asli serta standar deskripsi arsip statis.

Pengolahan arsip statis tentang asas asal usul yaitu pengolahan arsip statis yang berdasarkan asal usur arsip dilaksanakan melalui menata informasi arsip statisnya kemudian menata fisik arsip dan menyusun saran bantu temu balik arsip seperti daftar arsip statis.

Sarana Bantu Asas aturan asli arsip statis yaitu :

a. Guide;

b. Daftar arsip statis dan

c. invenstaris arsip.

Temu balik arsip Dinas Perpustakaan Dan Kearsipan Kota Pekanbaru menggunakan daftar arsip statis dan untuk asas mengenai aturan arsip statis yang asli di serahkan ke lembaga kearsipan tidak ada aturannya tetapi untuk peraturan bahwa arsip yang di serahkan merupakan arsip yang asli ada peraturannya.

Standar Deskripsi yaitu daftar arsip statis yang sekurang-kurangnya memuat

a. Pencipta arsip;

b. Nomor arsip;

c. Kode klasifikasi;

d. Uraian informasi arsip;

e. Kurun waktu;

f. Jumlah arsip, dan

g. Keterangan.

Sesuai dengan peraturan pemerintah Nomor 28 Tahun 2012 tentang Pelaksanaan Undang-undang Nomor 43 Tahun 2009 tentang Kearsipan.

\section{Preservasi Arsip Statis}


Preservasi arsip statis yaitu pengelolaan yang dilaksanakan dengan cara preventif dan kuratif.

Preservasi Arsip Statis yang dilaksanakan dengan cara Preventif yaitu cara penyimpanan arsip statis dengan pengendalian hama seperti fumigasi, mereproduksi arsip statis dan perencanaan tempat penyimpanan arsip statis ketika menghadapi bencana.

Sedangkan Preservasi Arsip Statis secara Kuratif yaitu perawatan arsip statis dengan memperhatikan contohnya membersihkan arsip statis dari debu, memberi kapur barus yang disimpan di dalam boks arsip.

\section{Akses Arsip Statis}

Akses arsip statis yaitu pengelolaan arsip statis yang dilaksanakan dalam rangka pemanfaatan, pendayagunaan, dan pelayanan publik.

Akses arsip statis yaitu pengelolaan arsip statis yang dilaksanakan dalam rangka pemanfaatan yaitu Pengguna arsip akan dijamin Akses arsip statisnya oleh lembaga kearsipan jika pengguna arsip membutuhkan arsip statisnya sesuai dengan peraturan perundang-undangan yang berlaku dan Untuk menjamin kepentingan akses arsip statis, Lembaga kearsipan sudah menyediakan sarana dan prasarana walaupun belum memadai tetapi lembaga kearsipan belum mempunyai ruang yang khusus untuk baca arsip statis bagi pengguna arsip statis.

Pengguna akses arsip statis tidak perlu kuatir dengan arsip statisnya yang disimpan di Dinas Perpustakaan dan Kearsipan Kota Pekanbaru karena Dinas Perpustakaan dan Kearsipan mempertimbangkan prinsip-prinsip keutuhan, keamanan dan keselamatan arsip statis itu sendiri.

Pengguna akses arsip statis bisa menentukan apakah arsip statisnya boleh di publish atau tidak di publish sesuai dengan peraturan perundang-undangan yang berlaku Akses arsip statis masih dilakukan secara manual belum menggunakan sistim elektronik.

Akses arsip statis yaitu pengelolaan arsip statis yang dilaksanakan dalam rangka Pendayagunaan adalah ketika pencipta arsip menyerahkan arsip ke Dinas Perpustakaan dan Kearsipan Kota Pekanbaru dengan memberikan persyaratan tertentu maka Dinas Perpustakaan dan Kearsipan Kota Pekanbaru akan melakukan hal yang diinginkan pencipta artis sesuai dengan perjanjian atau berita acara penyerahan arsip yang telah disepakati bersama dan disesuaikan dengan kebijakan atau peraturan perundang-undangan.

Akses Arsip Statis yang merupakan bagian dari Pelayanan Publik, dan jenis pelayanan publik untuk akses arsip statis yaitu Layanan Galeri Arsip merupakan akses arsip statis foto-foto Pekanbaru tempo dulu.

Layanan Penyerahan Arsip yaitu pemilik arsip menyerahkan arsip tekstual yang memiliki nilai sejarah dan Layanan peminjaman arsip dengan syarat dan ketentuan peraturan perundang-undangan arsip yang di pinjam berupa foto copy buka arsip yang asli. 
Apa saja kendala-kendala yang dihadapi dalam Pengelolaan Sistim Kearsipan Statis Pada Dinas Perpustakaan dan Kearsipan Kota Pekanbaru?

Kendala - kendala yang dihadapi dalam Pengelolaan Sistim Kearsipan Statis Pada Dinas Perpustakaan dan Kearsipan Kota Pekanbaru yaitu :

a. Sumber Daya Manusia yaitu

1. Kurangnya sumber daya manusia yang mempunyai keahlian di bidang kearsipan;

2. Pergantian Pejabat dan Staf Dinas Perpustakaan dan Kearsipan Kota Pekanbaru yang dilakukan sehingga dibutuhkan waktu untuk memahami dan mengetahui di bidang kearsipan.

b. Anggaran yaitu

1. Kurangnya anggaran untuk pelatihan sumber daya manusia di bidang kearsipan;

2. Kurangnya anggaran untuk penyediaan sarana dan prasana sehingga ruangan tempat penyimpanan tidak mencukupi untuk menyimpan arsip statis serta sarana pendukung ruangan penyimpanan seperti alat pendingin ruangan, lampu penerangan dan rak-rak atau lemari tempat menyimpan arsip statis.

c. Sarana dan Prasarana

1. Kurangnya luasnya ruangan tempat penyimpanan arsip statis sehingga arsip statis tidak tertata dengan rapi;

2. Kurangnya Sarana dan Prasarana seperti lemari, rak-rak dan filling cabinet untuk menyimpan arsip statis;

3. Kurangnya lampu penerangan sehingga ruangan tersebut tidak terlalu terang;

4. Kurangnya alat pendingin ruangan sehingga ruangan tersebut tidak nyaman;

5. Kurangnya sirkulasi udara sehingga ruangan penyimpanan arsip statis tersebut berbau tidak sedap.

\section{KESIMPULAN}

Pengelolaan Sistim Kearsipan Statis Pada Dinas Perpustakaan dan Kearsipan Kota Pekanbaru dengan indikator Akuisisi Arsip Statis, Pengolaham Arsip Statis, Preservasi Arsip Statis, dan Akses Arsip Statis dapat disimpulkan sebagai berikut :

\section{a. Akuisisi Arsip Statis}

Akuisisi Arsip Statis mempunyai 2 \{dua\} sub indikator yaitu Penyerahan Arsip Statis dan Hak Pengelolaannya dimana Penyerahan Arsip Statis sudah sesuai dengan Peraturan Pemerintah Republik Indonesia Nomor 28 Tahun 2012 tentang Pelaksanaan Undang-undang Nomor 43 Tahun 2009 tentang Kearsipan.

Penyerahan Arsip Statis pada Dinas Perpustakaan dan Kearsipan Kota Pekanbaru mempunyai nilai guna sejarah, telah habis retensinya, dan dilaksanakan 
oleh Lembaga Negara, Pemerintah Daerah, Perguruan Tinggi Negeri, BUMN, BUMD dan Perusahaan Swasta karena organisasi tersebut tidak mungkin tidak memiliki arsip statis.

Sedangkan Hak pengelolaan arsip statis yang telah diserahkan ke lembaga kearsipan menjadi wewenang lembaga kerasipan dan hak pengelolaan arsip statis perguruan tinggi swasta yang berkegiatan dibiayai dari anggaran negara atau APBD yang telah di serahkan ke lembaga kearsipan daerah menjadi wewenang lembaga kearsipan daerah.

\section{b. Pengolahan Arsip Statis}

Pengolahan Arsip Statis sudah sesuai dengan Peraturan Pemerintah Nomor 28 Tahun 2012 tentang Pelaksanaan Undang-undang Nomor 43 Tahun 2009 tentang Kearsipan mempunyai 3 \{tiga\} sub indikator yaitu Asas Asal Usul, Asas Aturan Asli dan Standar Deskripsi.

Pada Asas Asal Usul Pengolahan arsip statis dilaksanakan melalui menata informasi arsip statisnya kemudian menata fisik arsip dan menyusun saran bantu temu balik arsip seperti daftar arsip statis.

Sedangkan Asas Aturan Asli Untuk sarana bantu temu balik arsip Dinas Perpustakaan dan Kota Pekanbaru mengunakan daftar arsip statis. untuk asas mengenai aturan arsip statis yang asli di serahkan ke lembaga kearsipan tidak ada tetapi untuk peraturan bahwa arsip yang di serahkan merupakan arsip asli ada.

Standar Deskripsi yaitu Daftar arsip statis sekurang-kurangnya memuat Pencipta arsip, Nomor arsip, Kode klasifikasi, Uraian informasi arsip, Kurun waktu, Jumlah arsip, dan Keterangan.

\section{c. Preservasi Arsip Statis}

Preservasi Arsip Statis mempunyai 2 \{dua\} sub indikator yaitu : Preventif dan Kuratif sudah sesuai dengan Peraturan Pemerintah Nomor 28 Tahun 2012 tentang Pelaksanaan Undang-undang Nomor 43 Tahun 2009 tentang Kearsipan.

Preservasi Arsip Statis yang dilakukan cara Preventif dimana cara penyimpanan, pengendalian hama seperti fumigasi, reproduksi dan perencanaan jika menghadapai bencana.

Begitu pula dengan Preservasi Arsip Statis yang dilakukan dengan cara Kuratif dilakukan melalui perawatan arsip seperti membersihkan arsip dari debu, memberi kapur barus ke dalam boks arsip agar informasi yang terkandung di dalamnnya utuh.

\section{d. Akses Arsip Statis}

Akses Arsip Statis mempunyai 3 \{tiga\} sub indikator yaitu : Pemanfaatan, Pendayagunaan dan Pelayanan Publik sudah sesuai dengan Peraturan Pemerintah Nomor 28 Tahun 2012 tentang Pelaksanaan Undang-undang Nomor 43 Tahun 2009 tentang Kearsipan. 
Dimana Pemanfaatan Akses Arsip Statis di jamin oleh lembaga kearsipan jika lembaga kearsipan memiliki arsip yang dibutuhkan oleh pengguna arsip.

Sedangkan Pendayagunaan Jika ada kebijakan dan peraturan perundangundangan yang berhubungan dengan persyaratan akses arsip statis maka harus sesuai dengan kebijakan dan peraturan perundang-undangan tersebut.

Serta akses arsip statis merupakan bagian dari pelayanan publik.

Kendala-kendala yang dihadapi dalam Pengelolaan Sistim Kearsipan Statis Pada Dinas Perpustakaan dan Kearsipan Kota Pekanbaru yaitu :

a. Sumber Daya Manusia yaitu Kurangnya sumber daya manusia yang mempunyai keahlian di bidang kearsipan dan Pergantian Pejabat dan Staf Dinas Perpustakaan dan Kearsipan Kota Pekanbaru yang dilakukan sehingga dibutuhkan waktu untuk memahami dan mengetahui di bidang kearsipan.

b. Anggaran yaitu Kurangnya anggaran untuk pelatihan sumber daya manusia di bidang kearsipan dan Kurangnya anggaran untuk penyediaan sarana dan prasana sehingga ruangan tempat penyimpanan tidak mencukupi untuk menyimpan arsip statis serta sarana pendukung ruangan penyimpanan seperti alat pendingin ruangan, lampu penerangan dan rak-rak atau lemari tempat menyimpan arsip statis.

c. Sarana dan Prasarana yaitu Kurang luasnya ruangan tempat penyimpanan arsip statis sehingga arsip statis tidak tertata dengan rapi, Kurangnya Sarana dan Prasarana seperti lemari, rak-rak dan filling cabinet untuk menyimpan arsip statis, Kurangnya lampu penerangan sehingga ruangan tersebut tidak terlalu terang, Kurangnya alat pendingin ruangan sehingga ruangan tersebut tidak nyaman, dan Kurangnya sirkulasi udara sehingga ruangan penyimpanan arsip statis tersebut berbau tidak sedap.

\section{Saran}

a. Sumber Daya Manusia

1. Pemimpin dan staff merupakan ahli dibidang kearsipan artinya mempunyai latar belakang keilmuan dibidang kearsipan sehingga memahami pekerjaan di bidang kearsipan seperti Akuisisi Arsip Statis, Pengolahan Arsip Statis, Preservasi Arsip Statis, dan Akses Arsip Statis;

2. Pemimpin dan staff dalam menduduki jabatannya sesuai dengan peraturan perundang-undangan yang berlaku artinya baru menduduki jabatan 6 (enam) bulan sudah dipindahkan ke Dinas lainnya.

b. Anggaran

1. Dinas Perpustakaan dan Kearsipan Kota Pekanbaru menambah alokasi dananya untuk pelatihan di bidang kearsipan atau bagi staff yang berprestasi di sekolahkan dibidang kearsipan;

2. Dinas Perpustakaan dan Kearsipan Kota Pekanbaru menambah alokasi dananya untuk sarana dan prasarana seperti penyediaan ruangan tempat penyimpanan yang tidak mencukupi untuk menyimpan arsip statis serta 
sarana pendukung ruangan penyimpanan seperti alat pendingin ruangan, lampu penerangan dan rak-rak atau lemari tempat menyimpan arsip statis.

c. Sarana dan Prasarana

1. Dinas Perpustakaan dan Kearsipan Kota Pekanbaru menambah luasnya ruangan tempat penyimpanan arsip statis sehingga arsip statis bisa tertata dengan rapi;

2. Dinas Perpustakaan dan Kearsipan Kota Pekanbaru menambah Sarana dan Prasarana seperti lemari, rak-rak dan filling cabinet untuk menyimpan arsip statis;

3. Dinas Perpustakaan dan Kearsipan Kota Pekanbaru menambah lampu penerangan sehingga ruangan tersebut pencahayaannya terang;

4. Dinas Perpustakaan dan Kearsipan Kota Pekanbaru menambah alat pendingin ruangan sehingga ruangan tempat penyimpanan arsip tersebut nyaman, dan menambah sirkulasi udara ruangan sehingga ruangan penyimpanan arsip statis tersebut tidak berbau.

\section{DAFTAR PUSTAKA}

ANRI, 1979, Tata Kearsipan Statis, Jakarta : ANRI

Arikunto, Suharsini, 2002, Prosedur Penelitian Suatu Pendekatan Praktek, Jakarta, Rineka Cipta.

Abu bakar, A. H. Hadi, 1985 Pola Kearsipan Modern, Arsip Nasional RI, Jakarta.

Doni Juni Priansa \& Agus Garnida, 2013, Manajemen Perkantoran : Efektif, Efisien dan Profesional, Bandung, Alfabeta.

Laksmi, Fuad Gani \& Budiantoro, 2015, Manajemen Perkantoran Modern, Jakarta, PT. RajaGrafindo Persada.

Moleong J. Lexy, 2007. Metode Penelitian Kualitatif. Bandung, Remaja Rosdakarya.

Sedarmayanti, 2013 Tata Kearsipan : Dengan Memanfaatkan Teknologi Modern, Bandung, Mandar Maju

Undang-undang Republik Indonesia Nomor 43 Tahun 2009 tentang Kearsipan

Peraturan Pemerintah Republik Indonesia Nomor 78 Tahun 2012 tentang Kearsipan 